\title{
Clinical and sociodemographic analysis of people with ostomies: a cross-sectional study
}

\author{
Análise clínica e sociodemográfica de pessoas com estomias: estudo transversal
}

Análisis clínico y sociodemográfico de personas con estomas: estudio transversal

Ravena Rieelly Araujo Moura', Eliete Albano Azevedo Guimarães², Juliano Teixeira Moraes²

ORCID IDS

Moura RRA (D) https://orcid.org/0000-0002-2725-6167

Guimarães EAA (D) https://orcid.org/0000-0001-9236-8643

Moraes JT (iD https://orcid.org/0000-0002-1109-962X

\section{HOW TO CITE}

Moura RRA, Guimarães EAA, Moraes JT. Clinical and sociodemographic analysis of people with ostomies: a cross-sectional study, Braz. J. Enterostomal Ther., 16: e3818. https://doi.org/10.30086/estima. v16.637 IN

\begin{abstract}
:
Objectives: To analyze clinical and sociodemographic aspects of people with ostomies in the state of Minas Gerais. Methods: A cross-sectional study was conducted in 54 municipalities in 2016. Data were collected from 418 people with ostomies, registered from a structured questionnaire. Descriptive data analysis, the Pearson chi-square test and the Bonferroni correction were performed. Results: The majority of people with ostomies are elderly, male, have low schooling and low wage income. Colorectal malignant neoplasia was the main cause and $14.3 \%$ were treated with chemotherapy. Part of the ostomies is of the regular standing permanent colostomy type. The main complication highlighted is dermatitis, and $45.5 \%$ are not able to develop self-care. The type of ostomy was significantly associated with stomatal permanence, marital status and income $(p<0.05)$.Conclusion: People with ostomies need assistance related to self-care orientation, prevention and treatment of their complications.
\end{abstract}

DESCRIPTORS: Ostomy; Health profile; Health services; Health evaluation; Nursing; Stomatherapy.

\footnotetext{
${ }^{1}$ Universidade Federal de São João del-Rei - Contagem/MG - Brazil.

Universidade Federal de São João del-Rei - Curso de Enfermagem - Programa de Pós-Graduação - Divinópolis/MG - Brasil. Correspondence author: Ravena Rieelly Araujo Moura | Rua Mopage, 307 - Novo Eldorado | ZIP Code: 32341-200 - Contagem/MG Brazil | E-mail: ravena.araujo@yahoo.com.br Received: Aug 142018 | Accepted: Dec 152018
} 


\section{RESUMO}

Objetivos: Analisar aspectos clínicos e sociodemográficos de pessoas com estomias no estado de Minas Gerais. Métodos: Estudo de corte transversal realizado em 54 municípios, em 2016. Os dados foram coletados de 418 pessoas com estomia cadastradas a partir de um questionário estruturado. Realizou-se a análise descritiva dos dados, o teste de qui-quadrado de Pearson e a correção de Bonferroni. Resultados: A maioria das pessoas com estomias é idosa, do sexo masculino, tem baixa escolaridade e baixa renda salarial. A neoplasia maligna colorretal foi a principal causa e 14,3\% são tratados com quimioterapia. Parte das estomias é do tipo colostomias permanentes com forma regular. Destaca-se, como principal complicação, a dermatite, e 45,5\% não estão aptos a desenvolver o autocuidado. O tipo de estomia associou-se significativamente com a permanência da estomia, o estado civil e com a renda ( $p<0,05)$. Conclusão: As pessoas com estomias necessitam de assistência relacionada à orientação para o autocuidado, prevenção e tratamento de suas complicações.

DESCRITORES: Estomia; Perfil de saúde; Serviços de saúde; Avaliação em saúde; Enfermagem; Estomaterapia.

\section{RESUMEN}

Objetivos: Analizar aspectos clínicos y sociodemográficos de personas con estomas en el estado de Minas Gerais. Métodos: Estudio de corte transversal realizado en 2016 en 54 municipios. Los datos fueron recolectados de 418 personas con estoma registrados a partir de un cuestionario estructurado. Se realizó el análisis descriptivo de los datos, la prueba de chi-cuadrada de Pearson y la corrección de Bonferroni. Resultados: La mayoría de las personas con estomas es anciana, de sexo masculino, tiene baja escolaridad y baja renta salarial. La neoplasia maligna colorrectal fue la principal causa y 14,3\% son tratados con quimioterapia. Parte de las estomas es del tipo colostomías permanentes con forma regular. Se destaca, como principal complicación, la dermatitis, y 45,5\% no están aptos para desarrollar el autocuidado. El tipo de estoma se asoció significativamente a la permanencia del mismo, el estado civil y con el ingreso $(p<0,05)$. Conclusión: Las personas con estomas necesitan asistencia relacionada a la orientación para el autocuidado, prevención y tratamiento de sus complicaciones.

DESCRIPTORES: Estoma; Perfil de salud; Servicios de salud; Evaluación de salud; Enfermería; Estomaterapia.

\section{INTRODUCTION}

The person with an ostomy is the one who underwent surgery to make an ostomy. These include individuals of all ages and different sociodemographic profiles. The construction of an ostomy can be a therapeutic possibility of survival before clinical diagnosis, mostly of colorectal cancer, of fundamental importance for the physiological recovery and rehabilitation of this person ${ }^{1-3}$.

The most frequent elimination ostomies are urinary and intestinal. Urinaries are commonly referred to as urinary diversions, carried out in people with diseases involving the renal pelvis, ureters, bladder and urethra, and are intended to preserve renal function. Intestinal ostomies are indicated when some part of the intestine shows some dysfunction, obstruction or trauma. According to the anatomical location, the ostomy receives its own denomination, thus, the ileostomy is in the ileum and colostomy in the colon ${ }^{4-6}$.

The planning of care for the person with ostomy is based on the evaluation and monitoring of health practices, as well as knowledge of the sociodemographic and clinical characteristics of patients with ostomies, since this condition can influence the care beyond specific caring demands with the ostomy, such as changing eating habits, dressing style and the practice of sexual activities ${ }^{7}$.

Given the relevance of the health situation analysis, epidemiological data that depict the profile of people with ostomies are still scarce, mainly due to difficulties in systematizing health information7. The description of health conditions, sickness or illness is a necessary measure in the management of the services, programs and daily practices of these services. Thus, this study sought to analyze the clinical and sociodemographic conditions of people with stomies attended in six Health Care Services for the Ostomized Person (SASPO) in the state of Minas Gerais, Brazil.

\section{METHODS}

Cross-sectional study carried out in the western region of the state of Minas Gerais in 2016. This region covers 54 municipalities, with a total of $1,218,354$ 


\section{RESULTS}

inhabitants, and currently has six SASPO; of those, five are classified as type I and one as type $\mathrm{II}^{8}$.

Type I SASPO performs orientation actions for self-care, prevention of complications in the ostomies and supplies collecting equipment and adjuvants of protection and safety. Type II, in addition to developing the activities envisaged in the first, deals with complications that may arise and carries out training actions for professionals ${ }^{6}$.

The inclusion criteria for the data collection were: people with ostomies who were receiving care in the SASPO I and II and who had the cadastral record of the first nursing and medical evaluation at the time of insertion into the services, until the period of data collection, between January and April 2016. All records of patients with ostomies attended in the six services were analyzed, and the data were collected from their registry forms. These records contain information on sociodemographic variables (gender, marital status, age, schooling and family income), characteristics of the ostomies (ostomies, permanence, format, diameter and effluent disposal) and the conditions of these people (self-care, abdomen shape, cancer treatment and complications of the ostomies). A descriptive analysis of the data was performed, presenting the frequency distribution for categorical variables and position and dispersion measurements. The quantitative variable age has shown asymmetric distribution, according to the normality test Shapiro Wilk; thus, this was presented in median (P25 e P75). To compare proportions, the Pearson chi-square test was performed. It should be noted that, in order to identify the possible differences found, the $2 \times 2$ ratio analysis was used. In this analysis, we used the Bonferroni correction, which changes the level of significance ( $\mathrm{p}$ ) in order to avoid type I errors derived from multiple comparisons. The corrected level of significance after this procedure was $\mathrm{p}<0,016^{9}$.

The data were tabulated and analyzed with the help of the Epidata software (version 3.1) and the Statistical Package for the Social Sciences for Windows Student Version (SPSS), version 19.0. The level of statistical significance was set at $5 \%$.

This study was conducted according to the ethical rigour of Resolution 466/2012, with an opinion no. 1,251,725, approved by the Ethics Committee on Human Beings Research of the Federal University of São João del-Rei.
Data from 418 people with registered and active ostomies in the services were analyzed, distributed in $52.1 \%(\mathrm{n}=218)$ in the SASPO I and $47.9 \%(\mathrm{n}=200)$ in the SASPO II. Their ages ranged from 8 months to 97 years, with a median age of 64 years (P25:0; P75:97). More than half $(52.9 \%, \mathrm{n}=221)$ are males and $51.7 \%$ $(\mathrm{n}=216)$ are married.

Regarding schooling, 42.6\% $(\mathrm{n}=159)$ attended elementary school, followed by $28.4 \%(\mathrm{n}=106)$ semiilliterate students and $10.5 \%(n=39)$ illiterate students. The income between one and two wages was the most expressive, with $68.8 \%(\mathrm{n}=234)$.

Colorectal cancer was the main cause of ostomy practice, with $74.1 \%(\mathrm{n}=310)$. Other causes were bladder cancer, uterine cancer, Crohn's disease, Fournier gangrene, obstruction and intestinal perforation, representing $14.4 \%$ $(n=60)$. It was observed the occurrence of $11.5 \%(n=48)$ of people with ostomies without defined diagnoses.

The most frequent types were left colostomias $(51.6 \%, \mathrm{n}=215)$, right colostomies $(18.7 \%, \mathrm{n}=78)$ and ileostomies $(17 \%, \mathrm{n}=51)$.More than half $(56.6 \%, \mathrm{n}=237)$ had the definite ostomy and $73.2 \%(\mathrm{n}=271)$ had a regular shape.As for diameter, the largest occurrence was between 21-30 mm, with 29.9\% ( $\mathrm{n}=118)$, followed by $28.7 \%(\mathrm{n}=113)$ of the stomies, with $31-40 \mathrm{~mm}$. It was also found that more than half $(62.4 \%, \mathrm{n}=261)$ showed effluent elimination with pasty consistency.

The majority of people with ostomies $(88.3 \%, \mathrm{n}=369)$ used drainable pockets, with $56.8 \%(n=222)$ of the onepiece type. Regarding the use of other equipment and adjuvants for the care, were registered the indications of protective paste, a synthetic resin plate, belt and also, powder and urinary collector, totalling $41.4 \%(n=173)$.

Regarding the conditions of people with ostomies, $51.9 \%(\mathrm{n}=206)$ performed self-care with the ostomies and $23.4 \%(\mathrm{n}=93)$ needed assistance to perform care. Still, $94.4 \%(\mathrm{n}=368)$ were not bedridden and $22.8 \%$ $(\mathrm{n}=60)$ underwent radiotherapy or chemotherapy. Among the most frequent complications are peristomal dermatitis $(15.5 \%, \mathrm{n}=63)$, paraestomal hernia $(11.6 \%$, $\mathrm{n}=48)$, prolapse $(6.8 \%, \mathrm{n}=28)$ and retraction, $7 \%, \mathrm{n}=23)$

Table 1 shows the distribution of socio-demographic and clinical variables according to the type of ostomy.The 
analysis showed that the type of estomy was significantly associated with the marital status $(p=0.007)$,income $(p=0.024)$ and stomatal permanence $(p=0.001)$. After Bonferroni's correction, a greater proportion of unmarried and widowed individuals were found among those with colostomy than those with a urostomy $(n=191,45.8 \%$ vs. $\mathrm{n}=147,35.1 \%)$. The proportion of definitive ostomies was higher, with $88.2 \%(\mathrm{n}=369)$ among those with urostomy, $59.8 \%(\mathrm{n}=250)$ with colostomy and $36.4 \%$ $(\mathrm{n}=152)$ with ileostomy.
Table 2 shows the percentage distribution of sociodemographic and clinical variables according to the type of SASPO, and the results indicated that this was significantly associated with income $(\mathrm{p}<0.001)$, self-care $(\mathrm{p}<0.001)$ and chemotherapy or radiotherapy $(\mathrm{p}<0,040)$. It was observed that people with SASPO I ostomies presented higher income than those of SASPO II, being the proportion of income above two minimum wages and that people with SASPO II stomies had a higher proportion of non-self-care

Table 1. Percentage distribution of sociodemographic and clinical variables according to the type of stomies of people with stomies in the western region of the state of Minas Gerais, $2016(n=418)$.

\begin{tabular}{|c|c|c|c|c|c|}
\hline \multirow{2}{*}{$\begin{array}{l}\text { Socio-demographic and clinical } \\
\text { variables }\end{array}$} & Total & Ileostomy & Colostomy & Urostomy & \multirow{2}{*}{$p$-value* } \\
\hline & \multicolumn{4}{|c|}{ n (\%) } & \\
\hline Age (years) & & & & & 0.362 \\
\hline Under 20 & $18(4.3)$ & $1(1.5)$ & $14(4.6)$ & $3(6.2)$ & \\
\hline 20 to 59 & $146(34.9)$ & $29(40.9)$ & $103(35.2)$ & $13(25.0)$ & \\
\hline 60 or more & $254(60.8)$ & $41(57.6)$ & $176(60.2)$ & $37(68.8)$ & \\
\hline Gender & & & & & 0.079 \\
\hline Female & $194(46.5)$ & $34(47.9)$ & $143(48.8)$ & $17(32.1)$ & \\
\hline Male & $224(53.5)$ & $37(52.1)$ & $150(51.2)$ & $36(67.9)$ & \\
\hline Marital status & & & & & 0.007 \\
\hline Married or amassed & $246(58.9)$ & $46(64.7)$ & $159(54.2)$ & $41(76.5)$ & \\
\hline Single/widowed/others & $172(41.1)$ & $25(35.3)^{\mathrm{ab}}$ & $134(45.8)^{a}$ & $12(23.5)^{b}$ & \\
\hline Scholarship & & & & & 0.827 \\
\hline Illiterate & $163(38.9)$ & $29(41.3)$ & $115(39.2)$ & $18(33.3)$ & \\
\hline Elementary school & $178(42.6)$ & $32(44.4)$ & $121(41.5)$ & $25(46.7)$ & \\
\hline High school or college educated & $77(18.5)$ & $10(14.3)$ & $57(19.3)$ & $10(20.0)$ & \\
\hline Income (minimum wage) & & & & & 0.024 \\
\hline Up to 2 & $326(77.9)$ & $46(64.9)$ & $238(81.4)$ & $40(75.0)$ & \\
\hline More than 2 & $92(22.1)$ & $25(35.1)^{a}$ & $55(18.6)^{b}$ & $13(25.0)^{\mathrm{ab}}$ & \\
\hline Ostomy permanence & & & & & $<0.001$ \\
\hline Definitive & $249(59.5)$ & $26(36.4)$ & $175(59.8)$ & $47(88.2)$ & \\
\hline Temporary & $169(40.5)$ & $45(63.6)^{a}$ & $118(40.2)^{b}$ & $6(11.8)^{c}$ & \\
\hline Self-care & & & & & 0.452 \\
\hline Yes & $218(52.0)$ & $35(49.2)$ & $158(53.9)$ & $24(45.1)$ & \\
\hline No & $200(48.0)$ & $36(50.8)$ & $135(46.1)$ & $29(54.9)$ & \\
\hline Bedridden patient & & & & & 0.413 \\
\hline No & $394(94.3)$ & $65(92.2)$ & $276(94.2)$ & $52(98.0)$ & \\
\hline Yes & $24(5.7)$ & $6(7.8)$ & $17(5.8)$ & $1(2.0)$ & \\
\hline Undergoing chemotherapy or radiat & therapy & & & & 0.283 \\
\hline No & $323(77.2)$ & $49(68.8)$ & $233(79.5)$ & $40(76.0)$ & \\
\hline Yes & $95(22.8)$ & $22(31.3)$ & $60(20.5)$ & $13(24.0)$ & \\
\hline
\end{tabular}

Bold values meaning $p<0,001$. ${ }^{*}$ Chi-square test. The proportions with common letters in the line are statistically the same according to Bonferroni's correction ( $p>0.05$ ). Source: Health Service for the Ostomized Person (SASPO) of the western region of the state of Minas Gerais, 2016 
Table 2. Percentage distribution of sociodemographic and clinical variables according to the SASPO type of the western region of the state of Minas Gerais, $2016(n=418)$.

\begin{tabular}{|c|c|c|c|c|}
\hline \multirow{2}{*}{ Socio-demographic and clinical variables } & Total & Saspo I & Saspo II & \multirow{2}{*}{ p-value* } \\
\hline & & $\mathrm{n}(\%)$ & & \\
\hline Age (years) & & & & 0.325 \\
\hline Under 20 & $18(4.3)$ & $8(3.9)$ & $10(5.1)$ & \\
\hline 20 to 59 & $146(34.9)$ & $83(38.0)$ & $62(31.1)$ & \\
\hline 60 or more & $254(60.8)$ & $127(58.1)$ & $128(63.8)$ & \\
\hline Gender & & & & 0.583 \\
\hline Female & $194(46.5)$ & $98(45.1)$ & $96(47.8)$ & \\
\hline Male & $224(53.5)$ & $120(54.9)$ & $104(52.2)$ & \\
\hline Marital status & & & & 0.663 \\
\hline Married or amassed & $246(58.9)$ & $130(60.0)$ & $116(57.8)$ & \\
\hline Single/widowed/others & $172(41.1)$ & $88(40.0)$ & $84(42.2)$ & \\
\hline Scholarship & & & & 0.659 \\
\hline Illiterate & $163(38.9)$ & $81(37.3)$ & $82(41.0)$ & \\
\hline Elementary school & $178(42.6)$ & $93(42.8)$ & $84(42.2)$ & \\
\hline High school or college educated & $77(18.5)$ & $44(19.9)$ & $34(16.8)$ & \\
\hline Income (minimum wage) & & & & $<0.001$ \\
\hline Up to 2 & $326(77.9)$ & $153(70.0)$ & $175(87.5)$ & \\
\hline More than 2 & $92(22.1)$ & $65(30.0)$ & $25(12.5)$ & \\
\hline Ostomy permanence & & & & 0.659 \\
\hline Definitive & $249(59.5)$ & $131(60.3)$ & $116(58.1)$ & \\
\hline Temporary & $169(40.5)$ & $87(39.7)$ & $84(41.9)$ & \\
\hline Self-care & & & & $<0.001$ \\
\hline Yes & $218(52.0)$ & $140(64.4)$ & $78(39.2)$ & \\
\hline No & $200(48.0)$ & $78(35.6)$ & $122(60.8)$ & \\
\hline Pessoa com estomia acamada & & & & 0.496 \\
\hline No & $394(94.3)$ & $204(93.6)$ & $190(95.2)$ & \\
\hline $\begin{array}{l}\text { Yes } \\
\text { Yes }\end{array}$ & $24(5.7)$ & $14(6.4)$ & $10(4.8)$ & \\
\hline Undergoing chemotherapy or radiation therapy & & & & 0.040 \\
\hline $\begin{array}{l}\text { No } \\
-1\end{array}$ & $323(77.2)$ & $156(71.4)$ & $164(82.1)$ & \\
\hline Yes & $95(22.8)$ & $62(28.6)$ & $36(17.9)$ & \\
\hline
\end{tabular}

Bold values meaning $p<0,001 .{ }^{*}$ Chi-square test. The proportions with common letters in the line are statistically the same according to Bonferroni's correction ( $p>0.05$ ). Source: Health Service for the Ostomized Person (SASPO) of the western region of the state of Minas Gerais, 2016.

\section{DISCUSSION}

The data analysis revealed the occurrence of people with ostomies over 60 years, corroborating the national and international studies ${ }^{10-12}$. The elderly have unique characteristics and are more vulnerable to chronic-degenerative diseases, among them neoplasias, a disease of higher incidence in people over 50 years of age ${ }^{1}$. When it comes to the elderly, health professionals must understand that beyond the condition of having an ostomy, it may also occur the presence of other changes related to ageing that may also interfere with self-care.

There were no differences regarding sex, although the highest occurrence of ostomies was among men, which indicates a change in the profile of these people's illnesses ${ }^{10-13}$. Other studies in Brazil showed a higher prevalence of female ostomies by $2012^{2,5}$. Still, regarding gender, it is added that men seem to have more difficulty 
with emotional adjustment after surgery when compared with older women with ostomies ${ }^{14}$.

In this study, colorectal cancer was the main cause of stomatal confection, which is consistent with the diversity of national studies performed with ostomized people. In epidemiological terms, colorectal cancer represents the third most common neoplasm in both genders and the second leading cause of death in developed countries ${ }^{3,10,11}$. In Brazil, colorectal cancer is the second most frequent in women, with an estimated 17,620 new cases, and the third most incident in men, with 16,660 new cases. The estimated risk is 17.24 per 100,000 women and 15.44 new cases per 100,000 men $^{15}$.

Regarding schooling, the results showed, on the one hand, the predominance of people with low schooling and, on the other, that the level of education does not interfere with the type of ostomy performed.This finding points to the importance of health practices aimed at promotional activities that strengthen the self-care of people with ostomies. It is known that the lower the schooling, the greater the knowledge deficit on self-care, preventive measures and early detection of complications ${ }^{4}$. The higher educational level can also influence people's attitudes towards the ostomy and adaptive mechanisms and thus facilitate their new living conditions ${ }^{16}$. In this regard, education is a necessary tool that guarantees the participative inclusion of ostomized people in society, developing skills to face new adaptations in the face of physical, psychological and social transformations ${ }^{17}$.

The socioeconomic situation may also interfere with the quality of life of a person with an ostomy $y^{5}$. The population with low purchasing power may find it difficult to acquire the equipment and adjuvants necessary for good life quality, especially when some of these products are costly and not supplied by SASPO. The social aspects include the participation of the family, especially the spouse, as essential support in the therapeutic process, rehabilitation and social reintegration of the person with the ostomy ${ }^{18}$.

One of the problems faced by couples is the condition of having an ostomy and how much it can interfere with the sexual activity of the couple. A study carried out in Brazil showed that $36.1 \%$ changed their sexual practices and $30.6 \%$ ceased the intimate relations after the confection of the ostomy ${ }^{19}$. For spouses who have a partner with an ostomy, the elimination of gas, the presence of noise and odour exhaled by the ostomy are factors that disturb the intimacy of the couple.

With advances in technology, new collecting equipment and adjuvants of protection and safety to people with an ostomy are being developed, with the aim of reducing the problems related to the leakage of faeces, odours and gases that interfere in the activities of daily life and generate a feeling of fear and shame ${ }^{19,20}$. In addition, it becomes essential to familiarize with the new devices, selecting them appropriately according to the needs of each type of ostomy.

As for the kind of ostomy, there was a predominance of colostomy, followed by an ileostomy, corroborating national $1^{10,11}$ and international ${ }^{3,12}$ studies. The colostomy results from a surgical intervention performed in colorectal cancer treatments, usually of a definitive character and, therefore, has a great impact on the life condition of the stomatal carriers and their family ${ }^{5,11}$.

The greater occurrence of colostomized persons suggests the planning of a care routine that can reduce the presence of peristomial lesions and enable this person to perform irrigation, guiding how much time between feeding and evacuation, the condition of absorption of food and medication, among others ${ }^{21}$.

It is evident the association between definitive ostomies for colorectal and urogenital cancers and of temporaries associated with trauma ${ }^{10,12}$. The period of the permanence of the stomies is directly related to the diagnosis that indicated their confection. It is temporary when a certain period of time is established, which can be from months to years, due to the need to protect an intestinal anastomosis or abdominal trauma. It is definitive when the person with an ostomy will have to live with the ostomy indefinitely, performed to replace the loss of sphincter function resulting from a surgical treatment ${ }^{11,18}$.

Regarding the shape of the stoma, the regular type reduces complications, especially by promoting the adaptation of the collecting equipment ${ }^{13}$.In this study, most of the stomies were identified with a diameter of 21-30 mm. Identifying the diameter of the stoma is essential for the appropriate care plan that will enable proper selection of the equipment and adjuvant and the ideal adaptation of the adhesive base of skin barrier to the ostomy, avoiding peristomial cutaneous lesions and promoting greater comfort for the person ${ }^{10,18}$. 
The making of an ostomy is potentially accompanied by complications, which are mostly underestimated. Studies have shown that rates of ostomy-related complications reach $60 \%^{12,13}$. From the postoperative complications presented in the stoma and the skin, dermatitis, hernia, and prolapse were recorded in the medical files of people with ostomies of the studied region. The origin of the complications may be a consequence of the absence of preoperative consults, especially in the lack of preoperative stomatal demarcation, since poor localization makes self-care difficult, as skin visualization and equipment exchange ${ }^{18}$. Such complications may result in discomfort due to frequent effluent leakage and inadequate adaptation of the plaque in the ostomy.

It was also identified the use of drainable or open collecting equipment of the one piece system type by ostomized people. In Brazil, another study has shown a similar result in that $94.4 \%$ of these people used the onepiece bag, and all bags were drainable or of open type ${ }^{13}$.

It should be noted that the indication of the collecting system must be individualized, so as to consider the characteristics of each person's ostomy, as well as their educational level. There is a greater recommendation of the one-piece system, because this equipment requires fewer instructions, being the most practical option for the health professionals, the person with the ostomy and the less educated caregiver. Even though this is the best option, this population still considers all the information very complex and considers themselves incapable of learning, since the majority of this public has low education ${ }^{8,10,13,18}$.

In the analysis, it was found that, in addition to the bags provided monthly by the service, people with ostomies receive other adjuvant materials, such as plaques, powders and pastes, which are also provided by the Unified Health System (Sistema Único de Saúde -SUS), and the indications of the equipment and adjuvants depend on the type of Stomatology, the consistency of the effluent and the surgical performed ${ }^{10,13}$.

The results indicated that half of the patients with stomies do self-care. However, the approach used in this research did not make it possible to investigate the quality of this care. Other studies carried out in different regions of Brazil indicated that most people with ostomies had difficulty performing it due to a lack of guidance or assistance from trained professionals during this stage of treatment ${ }^{1,10}$. The emphasis on selfcare has been described as an alternative for the person with the ostomy to actively participate in their own care, stimulating responsibility for continuing the care which can avoid complications and achieve rehabilitation.

Although there was statistical significance between the associations of sociodemographic and clinical characteristics with the type of ostomy, as well as the types of SASPO with self-care and the accomplishment of cancer treatment, these results are not clinically significant, meaning the interpretation of the results of the studies showed statistically significant but not clinically significant results because they were not useful in daily clinical practice.

As a limitation of this study is the fact that, because only persons with stomies linked to public health services (SUS) were surveyed, it is not possible to infer the real profile of this population in the region. Other limitations were related to the incompleteness of blank fields found in the records of the first evaluation of the Saspo team, at the time of insertion of people with ostomies to the services, and in the form standardized by the State Secretary of Health of Minas Gerais (SES/ $\mathrm{MG})$, which needs updating.

This information can support the development of proposals for health action strategies to improve health practices and, consequently, the quality of care for people with ostomies.

\section{CONCLUSION}

The people with ostomies attended in the SASPO evaluated are mostly elderly, with a low level of education and low wage income. Colorectal malignant neoplasia was the main cause and the definitive colostomy type of ostomy was the most frequent. The most commonly used collectors are the drainable type, one-piece system, using adjuvants such as plates, pastes and powders.

This study presented as positive points: to reveal the results on the clinical and sociodemographic characteristics of people with ostomies, as necessary information for decision making facing the organization of local services; to advise on the need to review the standard form used by SES / MG, as well as the training 


\section{CONTRIBUTION OF AUTHORS}

of professionals involved in service activities, improving the records of the assistance provided to these clients. Persons with ostomies needs assistance regarding guidance for self-care, prevention and treatment of complications of the stomies.
Conceptualization, Moura RRA; Guimarães EAA e Moraes JT; Methodology, Guimarães EAA e Moraes JT; Investigation, Moura RRA e Moraes JT; Writing - First version, Moura RRA; Guimarães EAA e Moraes JT; Writing

- Reviewing \& Editing, Guimarães EAA e Moraes JT.

\section{REFERENCES}

1. Silva J, Sonobe HM, Buetto LS, Santos MG, Lima MS, Sasaki VDM. Estratégias de ensino para o autocuidado de estomizados intestinais. Rev Rene (Online). 2014;15(1):16673. https://doi.org/10.15253/2175-6783.2014000100021

2. Melotti LF, Bueno IM, Silveira, GV, Silva MEN, Fedosse E. Characterization of patients with ostomy treated at a public municipal and regional reference center. J Coloproctol (Rio J). 2013;33(2):70-4. https://doi.org/10.1590/S2237-936320130 00200005

3. Sasaki VDM, Pereira APS, Ferreira AM, Pinto MH, Gomes J. Health care service for ostomy patients: profile of the clientele. J Coloproctol (Rio J). 2012;32(3). https://doi. org/10.1590/s2237-93632012000300005

4. Lenza NFB, Sonobe HM, Buetto LS, Santos MG, Lima MS. O ensino do autocuidado aos pacientes estomizados e seus familiares: uma revisão integrativa. Rev Bras Promoç Saúde, Fortaleza. 2013;26(1):139-45.

5. Luz ALA, Luz MHBA, Antunes A, Oliveira GS, Andrade EMLR, Miranda SM. Perfil de pacientes estomizados: revisão integrativa da literatura. Cultura de los Cuidados. 2014;18(39):115-23. https://doi.org/10.7184/cuid.2014.39.13

6. Ministério da Saúde (BR). Secretaria de Atenção à Saúde. Portaria n 400, de 16 de novembro de 2009. [Internet]. Brasília, DF; 2009. Disponível em: http://www.ans.gov.br/ images/stories/noticias/pdf/p sas 4002009 ostomizados.pdf

7. Moraes JT, Amaral CFS, Borges EL, Ribeiro MS, Guimarães EAA. Serviços de atenção ao estomizado: análise diagnóstica no estado de Minas Gerais, Brasil. Cad Saúde Colet, Rio de Janeiro. 2014;22(1):101-8. https://doi.org/10.1590/1414$462 \times 201400010015$

8. Ribeiro MS, Borges EL. Linha de cuidados da pessoa estomizada. Belo Horizonte: Secretaria de Estado de Saúde de Minas Gerais; 2015.

9. Field A. Descobrindo a estatística usando o SPSS. 2a ed. Porto Alegre: Artmed; 2005

10. Salomé GM, Carvalho MRF, Junior MRM, Mendes B. Profile of ostomy patients residing in Pouso Alegre city. J Coloproctol (Rio J). 2015;5(2):106-12. https://doi.org/10.1016/j.jcol.2015. $\underline{02.002}$

11. Neto MAFL, Fernandes DOA, Didoné EL. Epidemiological characterization of ostomized patients attended in referral center from the city of Maceió, Alagoas, Brazil.
J Coloproctol (Rio J). 2016;36(2):64-8. https://doi.org/10.1016/j. jcol.2014.08.016

12. Joyce P. Characteristics of the patient with an ostomy. J Wound Ostomy Continence Nurs. 2011;38(3):271-9. https:// doi.org/10.1097/WON.0b013e3182152bbf

13. Miranda SM, Luz MHBA, Sonobe HM, Andrade EMLR, Moura ECC. Caracterização sociodemográfica e clínica de pessoas com estomia em Teresina. ESTIMA, Braz J Enterostomal Ther. 2016;14(1):29-35. https://doi.org/10.5327/Z1806-31442016 00010005

14. Skeps R, McMullen CK, Wendel CS, Bulkley J, Grant M, Mohler J et al. Changes in body mass index and stoma related problems in the elderly. J Geriatr Oncol. 2013;4(1):84-9. https://doi.org/10.1016/i.jo.2012.10.172

15. Ministério da Saúde (BR). Instituto Nacional de Câncer. Estimativa 2016: incidência de câncer no Brasil [Internet]. Brasília, DF: 2016. Disponível em: https://www.inca.gov. br/campanhas/dia-nacional-de-combate-ao-cancer/2015/ estimativa-2016-incidencia-de-cancer-no-brasil

16. FanCheng MD, Ai-fengMeng BD, Li-Fang Yang BD, Yi-nan Zhang, BD. The correlation between ostomy knowledge and self-care ability with psychosocial adjustment in Chinese patients with a permanent colostomy: a descriptive study. Ostomy Wound Manage. 2013;59(7):35-8.

17. Grant Ma, Corkle RM, Hornbrook MC, Wendel SC, Krouse R. Development of a chronic care ostomy self-management program. J Cancer Educ. 2013;28(1):70-8. https://doi. org/10.1007/s13187-012-0433-1.

18. Silva AC, Silva GNS, Cunha, RR. Caracterização de pessoas estomizadas atendidas em consulta de enfermagem do Serviço de Estomaterapia do Município de Belém-PA. ESTIMA, Braz J Enterostomal Ther. 2012;10(1).

19. Silva AL, Kamada I, Sousa JB, Vianna AL, Oliveira PG. Singularidades da convivência do cônjuge e seu parceiro estomizado. ESTIMA, BrazJ EnterostomalTher.2016;14(2):6875. https://doi.org/ 10.5327/Z18063144201600020004

20. Diebold L. Stoma and shame: engaging affect in the adaptation to a medical device. Aust J Adv Nurs. 2016;34(1):32-41.

21. Moraes JT, Assunção RS, Sá FS, Lessa ER, Corrêa LS. Perfil de pessoas estomizadas de uma região de saúde mineira. Enferm Foco. 2016;7(2):22-6. 